\title{
Population dynamics of a hypoxia-tolerant bivalve: A comparison of two sites in the inner part of Ariake Bay, Japan
}

\author{
Ryo Orita $^{1, \dagger}, *$, TOMOHIRo Komorita ${ }^{1}$, Mutsuo ICHINOMIYA ${ }^{1} \&$ HiroAKi Tsutsumi $^{1}$ \\ ${ }^{1}$ Faculty of Environmental and Symbiotic Sciences, Prefectural University of Kumamoto, 3-1-100 Tsukide, \\ Kumamoto 862-8502, Japan \\ ${ }^{\dagger}$ Present address: Faculty of Agriculture, Saga University, 1 Honjo-machi, Saga 840-8502, Japan
}

Received 1 February 2018; Accepted 9 May 2021 Responsible Editor: Shigeaki Kojima

doi: $10.3800 /$ pbr. 16.249

\begin{abstract}
Hypoxia-tolerant bivalve populations could be a key component of ecosystem function because of their predominance in hypoxic environments. In this study, we conducted field surveys at two sites to elucidate the biological traits of the hypoxia-tolerant bivalve Veremolpa micra. We detected new settlements at both sites during summer. More highly reduced conditions in the surface sediment were recorded at Site-A than at Site-B in August 2013. Following this hypoxic event, shell growth of V. micra at Site-A decelerated, whereas that at Site-B increased. The population density after recovery from the hypoxic event decreased more at Site-B than at Site-A. Body size exhibited very little growth at both sites during the fall and winter, but there was rapid growth during the subsequent spring and summer, with sexual maturity being reached in early summer. Our findings demonstrated that the growth rates and survival patterns of the hypoxia-tolerant bivalve populations differed between sites with different degrees of sediment reduction. To understand the biological traits of hypoxia-tolerant bivalve species, it is necessary to consider and evaluate spatial differences in hypoxic stress at the local site level.
\end{abstract}

Key words: Ariake Bay, Hypoxia, Life history, Population dynamics, Veremolpa micra

\section{Introduction}

Veremolpa micra (Pilsbry, 1904) is a small bivalve belonging to the family Veneridae (Matsukuma 2000). Although $V$. micra has often been reported as the dominant species in the semi-enclosed bays of western Japan (e.g., Yokoyama \& Hayashi 1980, Antonio et al. 2010, Yoshino et al. 2010, Orita et al. 2015), their life history has hardly been studied. Only Tanaka \& Kikuchi (1979) reported the population dynamics of $V$. micra in the field; basic information, such as reproductive ecology and mortality factors, is scarce.

In the inner part of Ariake Bay, where seasonal hypoxia occurs, V. micra has been reported as a predominant species (Yoshino et al. 2010, Orita et al. 2015). Additionally, $V$. micra collected from this region was highly tolerant to anoxic conditions (Yamada et al. 2016). According to a long-term survey from 2002 to 2008 in Ariake Bay by

\footnotetext{
*Corresponding author: Ryo Orita; E-mail,ss7427@cc.saga-u.ac.jp
}

Tsutsumi et al. (2015), the density of V. micra at Stn A fluctuated greatly and was mainly composed of small individuals, whereas the population of $V$. micra at Stn B, which was adjacent to Stn A, had a high density and biomass. Quantifying some biological traits of V. micra at these two sites with different population dynamics and documenting the environmental factors that affect the biological traits are important to understand the ecological characteristics of this species.

In this investigation, we conducted field surveys at two sites (Fig. 1, Stn A and B of Tsutsumi et al. 2015) in the inner part of Ariake Bay to elucidate the biological traits of the hypoxia-tolerant bivalve V. micra. We monitored several environmental factors and the biological traits of $V$. micra, including population density, biomass, shell-size frequency, secondary production, sexual maturation, and the condition of residual shells. We then compared the biological traits of $V$. micra between sites and discussed the environmental factors that affected the differences in biological traits of this hypoxia-tolerant bivalve. 


\section{Materials and Methods}

\section{Study sites}

Ariake Bay is a semi-enclosed bay, located on the west coast of Kyushu, western Japan. The inner part of Ariake Bay coincides with several major river mouths. The water column stratifies during the rainy season (mid-June) to late summer (September) (Tsutsumi 2006). Hypoxic water primarily occurs in muddy sediment areas following water stratification. In this study, we sampled two muddy sediment sites, Site-A and Site-B (Fig. 1), where different population dynamics of $V$. micra were recorded by Tsutsumi et al. (2015).

\section{Field surveys}

Field surveys were conducted once a month during the neap tide from July 2013 to September 2014 (except December 2013 and February, March, and June 2014), because the intensity of hypoxia increases during neap tide in the inner part of Ariake Bay (e.g., Tanaka et al. 2007). The influence of hypoxia on $V$. micra was evaluated using dissolved oxygen (DO) and water temperature because these factors are known to affect oxygen thresholds in benthic organisms (Vaquer-Sunyer \& Duarte 2011). At each site, we measured DO and temperature of the water just above the seafloor (within $10 \mathrm{~cm}$ of the seafloor) using a multiprobe sensor (YSI 6600, Yellow Springs Instruments, USA), and sediment samples were collected four times using an Ekman-Birge grab sampler $(20 \times 20 \mathrm{~cm})$. From one of the sediment samples, we subsampled the surface layer up to a depth of $1 \mathrm{~cm} 10$ times using plastic cores with $29 \mathrm{~mm}$ diameters to determine chemical characteristics.
With regard to chemical characteristics of the sediment, we monitored chlorophyll $a$ (Chl-a) content and acid volatile sulfide (AVS; $\mathrm{H}_{2} \mathrm{~S}+\mathrm{FeS}$ ) as indicators of food supply and reduced conditions, respectively. These factors help elucidate temporal changes in the water as organic production increases because of an increase in the number of phytoplankton. Thus, sediments are deposited and the history of hypoxia remains similar to that of reduced sediments (Nilsson \& Rosenberg 2000, Middelburg \& Levin 2009). The remaining three sediment samples were used for quantitative sampling of the macrobenthos. Each was sieved using a $1 \mathrm{~mm}$ mesh. All samples were stored in a cooler and transported to the laboratory.

\section{Sample analysis}

Chl- $a$ content and AVS levels of the sediment were measured as described by Orita et al. (2015). The macrobenthos samples were fixed in a $10 \%$ formalin solution and stained with Rose Bengal. All macrobenthos samples were sorted, identified, and counted. The shell length (SL; mm) of $V$. micra was measured to the nearest $0.01 \mathrm{~mm}$ under a stereomicroscope (Leica, M205C) using the ImageJ 1.46 software (National Institutes of Health, USA). All residual shells of $V$. micra stained by Rose Bengal were collected from macrobenthos samples in July 2014 to determine the cause of the decline in population density.

\section{Estimation of secondary production}

Individuals with different body sizes were randomly selected, and the dry weight of the soft tissues with the shell (DW; $\mathrm{mg}$ ) was measured after drying at $55^{\circ} \mathrm{C}$ for $12 \mathrm{~h}$. The regression equation of DW versus SL was determined as follows:

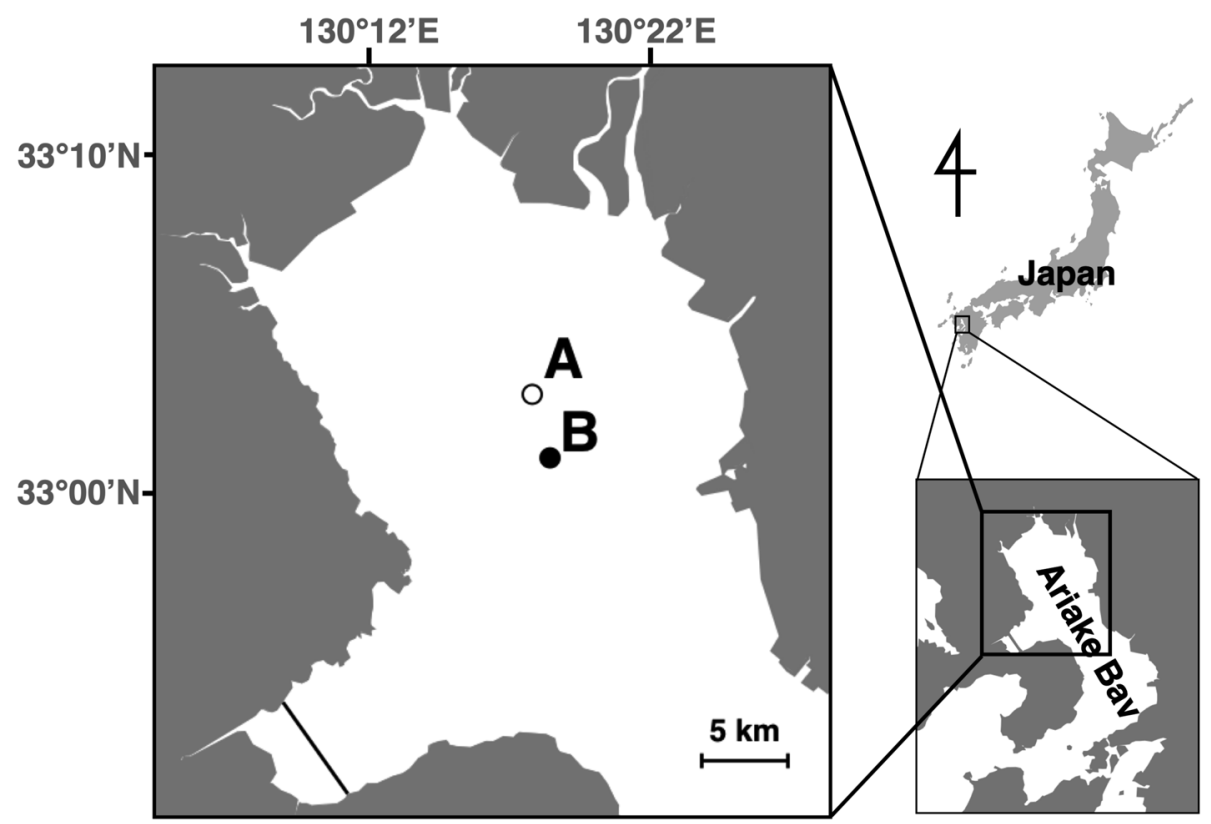

Fig. 1. Study area and sampling sites in the inner part of Ariake Bay. Open circle: Site-A. Closed circle: Site-B. These two sites correspond to the sampling stations of Tsutsumi et al. (2015). 


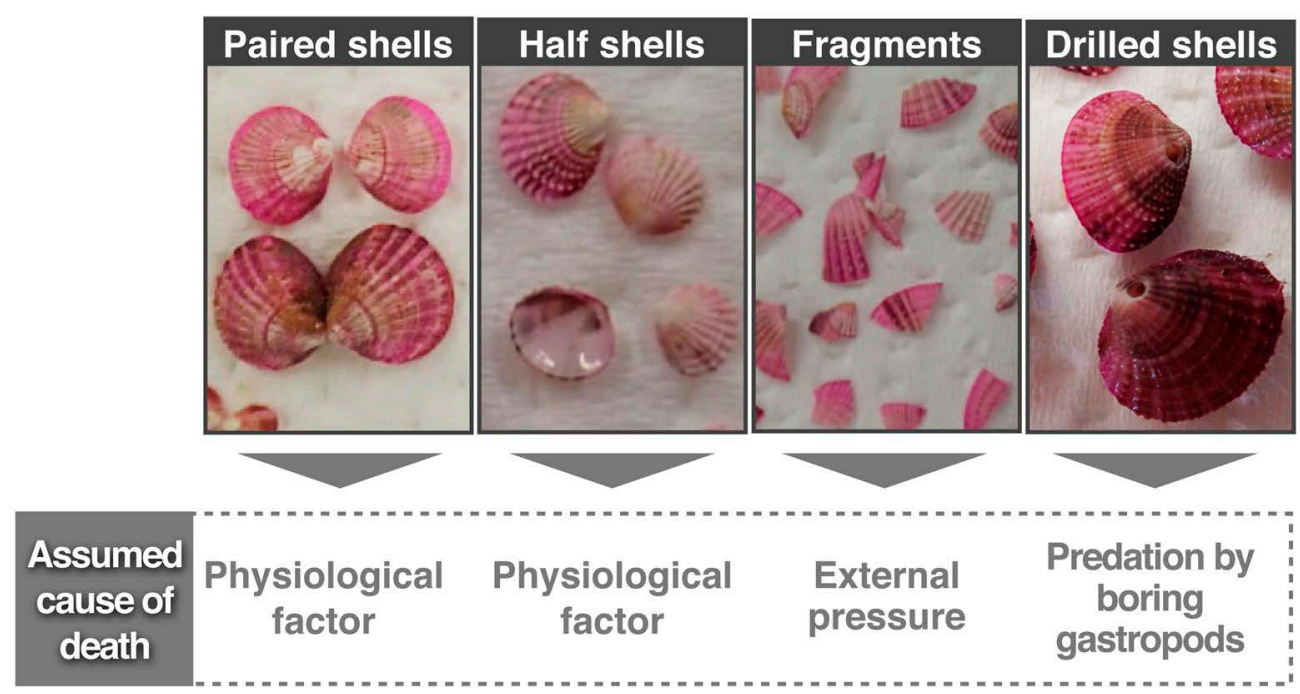

Fig. 2. Classification of residual shells stained by Rose Bengal. Each type of residual shells assumes mortality factors for $V$. micra (paired shells and half shells represent the physiological factor; fragments represent the physical factor wherein the shell is broken by external pressure; drilled shell represents the predation by boring gastropods).

$$
D W=0.2217 S L^{2.6053}, \quad r^{2}=0.9864, n=79
$$

The secondary production of $V$. micra was calculated using an incremental summation method (cf. Tamai 1988). Secondary production of $V$. micra in each sampling period was estimated using the following equation:

$$
P=\frac{(D(t)+D(t+1))}{2} \times(\mathrm{B}(t+1)-\mathrm{B}(t))
$$

where $P$ is the secondary production $\left(\mathrm{g} \mathrm{DW} \mathrm{m}^{-2}\right)$ of $V$. micra in each sampling period between sampling times $t$ and $(t+1), D$ is the density (ind. $\mathrm{m}^{-2}$ ), and $B$ is the average individual mg DW calculated from the average SL using Eq. 1. The annual secondary production of $V$. micra was calculated by summing the values of secondary production for each period from August 2013 to August 2014.

\section{Monitoring of sexual maturation}

To monitor sexual maturation during April and July 2014, the condition index (CI) was calculated using the following equation: $\mathrm{CI}=$ wet weight of soft tissue of $V$. micra $(\mathrm{mg}) /[\mathrm{SL} \times$ shell height $(\mathrm{mm}) \times$ shell width $(\mathrm{mm})]$, and the gonads were observed under an optical microscope $(n=5$, during each sampling occasion).

\section{Classification of residual shells}

All residual shells of $V$. micra stained by Rose Bengal were classified into four types: paired shells (shells were jointed and unbroken), half shells (shells were unbroken), fragments (shells were broken), and drilled shells (shells containing a hole) (Fig. 2). These types were used to determine the factors responsible for the mortality of $V$. micra. We assumed that paired and half shells represented the physiological factor, fragments represented the physical factor, where the shell was broken by external pressure, and the drilled shells represented predation by boring gastropods (Fig. 2). The DW of each type of shell was determined, and a generalized linear model (GLM, gamma distribution, log-link function) was used to estimate the influence of the sites (explanatory variables: Site-A and SiteB) on the weight of each type (response variables: paired shells, half shells, and fragments). Significant differences in the residual shell biomass between sites (i.e., GLMs of each type) were analyzed using the likelihood-ratio test (chi-square distribution). All statistical analyses were conducted using the R software (version 3.2.2).

\section{Results}

\section{Benthic environment during summer}

The mean water temperatures just above the seafloor during summer months (July to September) were $25.9^{\circ} \mathrm{C}$ at Site-A and $25.7^{\circ} \mathrm{C}$ at Site-B in 2013 and $24.6^{\circ} \mathrm{C}$ at Site-A and $24.5^{\circ} \mathrm{C}$ at Site-B in 2014 , with little differences between sites each year (Table 1). The DO levels just above the seafloor were slightly different between sites in summer 2013, with lower values recorded at Site-A than Site-B in all months, and hypoxic water $\left(1.6 \mathrm{mg} \mathrm{L}^{-1}\right.$ at Site-A and $2.6 \mathrm{mg} \mathrm{L}^{-1}$ at Site-B) observed in August. Hypoxic water was not observed at either site in summer 2014. Chl- $a$ content and AVS levels in the surface sediment were higher at Site-A than at Site-B in each year (Table 1). The highest AVS levels were observed in August 2013 at both sites, especially at Site-A, where a reduction in the surface sediment was in progress during that month.

\section{Density, biomass, and size-frequency distribution}

The mean density and biomass of $V$. micra during the sampling period were $934.8 \pm 628.8 \mathrm{ind} \mathrm{m}^{-2}$ (mean $\pm \mathrm{SD}$ ) and 
Table 1. Comparison of benthic environmental parameters between the sampling sites during summer*

\begin{tabular}{|c|c|c|c|c|c|c|}
\hline Environmental parameter & Year & Site & Mean & SD & Max. & Min. \\
\hline \multicolumn{7}{|l|}{ Bottom water } \\
\hline \multirow[t]{4}{*}{ Temperature $\left({ }^{\circ} \mathrm{C}\right)$} & 2013 & $\mathrm{~A}$ & 25.9 & 0.8 & 26.6 (Aug.) & 24.7 (Jul.) \\
\hline & & $\mathrm{B}$ & 25.7 & 1.3 & 26.8 (Sep.) & 23.9 (Jul.) \\
\hline & 2014 & A & 24.6 & 1.0 & 25.5 (Aug.) & 23.2 (Jul.) \\
\hline & & $\mathrm{B}$ & 24.5 & 1.2 & 25.5 (Aug.) & 22.9 (Jul.) \\
\hline \multirow[t]{4}{*}{$\mathrm{DO}\left(\mathrm{mg} \mathrm{L}^{-1}\right)$} & 2013 & A & 2.5 & 0.9 & 3.3 (Sep.) & 1.6 (Aug.) \\
\hline & & $\mathrm{B}$ & 3.2 & 0.6 & 3.8 (Sep.) & 2.6 (Aug.) \\
\hline & 2014 & A & 4.8 & 0.9 & 5.7 (Sep.) & 4.0 (Jul.) \\
\hline & & $\mathrm{B}$ & 4.8 & 0.3 & 5.2 (Aug.) & 4.5 (Jul.) \\
\hline \multicolumn{7}{|l|}{ Surface sediment } \\
\hline \multirow[t]{4}{*}{ Chl- $a\left(\mu \mathrm{g} \mathrm{g}^{-1}\right)$} & 2013 & A & 25.2 & 4.2 & 30.1 (Sep.) & 22.7 (Jul.) \\
\hline & & $\mathrm{B}$ & 10.1 & 6.6 & 17.5 (Jul.) & 5.1 (Sep.) \\
\hline & 2014 & A & 14.9 & 7.8 & 23.9 (Jul.) & 10.1 (Sep.) \\
\hline & & $\mathrm{B}$ & 4.9 & 1.1 & 5.5 (Jul.) & 3.6 (Aug.) \\
\hline \multirow[t]{4}{*}{$\operatorname{AVS}\left(\mathrm{mg} \mathrm{g}^{-1}\right)$} & 2013 & A & 0.38 & 0.14 & 0.53 (Aug.) & 0.25 (Jul.) \\
\hline & & B & 0.13 & 0.06 & 0.18 (Aug.) & 0.07 (Sep.) \\
\hline & 2014 & A & 0.20 & 0.13 & 0.35 (Jul.) & 0.11 (Aug.) \\
\hline & & $\mathrm{B}$ & 0.06 & 0.03 & 0.10 (Sep.) & 0.04 (Aug.) \\
\hline
\end{tabular}

* Period from July to September (for three months)

14.6 $\pm 25.0 \mathrm{gWW} \mathrm{m}^{-2}$ at Site-A and 2136.4 \pm 2246.1 ind $\mathrm{m}^{-2}$ and $21.4 \pm 24.3 \mathrm{gWW} \mathrm{m}^{-2}$ at Site-B. The size-frequency distribution of $V$. micra revealed a growing cohort at both sampling sites (Fig. 3). New settlements were found at both sites in August 2013. During August and September 2013, a substantial difference was observed in the growth rates between the sites. The shell growth of individuals at SiteA was more delayed than that at Site-B. The maximum shell length of the cohort at Site-A was $2.5 \mathrm{~mm}$, whereas at Site-B it reached $4.5 \mathrm{~mm}$ in September 2013 (mean \pm SD, Site-A: $1.8 \pm 0.2$, Site-B: $2.5 \pm 0.6$ ). This difference in shell length between sites was maintained until early spring 2014. Population density at Site-A slightly decreased from October 2013 to May 2014 (from 222 to 99 individuals), whereas at Site-B it greatly decreased during the same period (from 761 to 90 individuals). At both sites, the shell length of $V$. micra exhibited rapid growth during May and July 2014 and subsequently decreased with population density in August 2014. A new settlement in the subsequent cohort occurred in September 2014.

\section{Secondary production}

Figure 4 shows the secondary production of $V$. micra in each sampling period between August 2013 and August 2014. The first peak of secondary production was observed between September and October 2013, with $5.0 \mathrm{~g} \mathrm{DW} \mathrm{m}^{-2}$ at Site-A and $21.2 \mathrm{~g} \mathrm{DW} \mathrm{m}^{-2}$ at Site-B. During the period between October 2013 and May 2014, the secondary production was low at both sites, with mean values of $1.1 \mathrm{~g} \mathrm{DW} \mathrm{m}^{-2}$ at Site-A and $0.8 \mathrm{~g} \mathrm{DW} \mathrm{m}^{-2}$ at Site-B. A second peak in secondary production was observed between May and July 2014, reaching $46.1 \mathrm{~g} \mathrm{DW} \mathrm{m}^{-2}$ at Site-A and $19.2 \mathrm{~g} \mathrm{DW} \mathrm{m}^{-2}$ at Site-B. The total annual secondary production of $V$. micra was $51.4 \mathrm{~g} \mathrm{DW} \mathrm{m}^{-2}$ year $^{-1}$ at Site-A and $48.2 \mathrm{~g} \mathrm{DW} \mathrm{m}^{-2}$ year $^{-1}$ at Site-B.

\section{Sexual maturity}

The CI of $V$. micra increased from April 2014 (mean \pm SD, $0.08 \pm 0.02$ ) to July 2014 [0.15 \pm 0.01 ; Fig. 5(a)]. On observing through an optical microscope, all individuals were regarded as immature in April and May 2014, whereas most were matured (one individual contained eggs, whereas the other three individuals contained sperm) by July 2014 [Fig. 5(b)]. Some individuals spawned during sample treatment in July 2014 [Fig. 5(c)].

\section{Condition of residual shells}

Half shells and fragments were significantly more abundant at Site-B, as determined by the likelihood-ratio test $(p<0.001)$, and drilled shells were detected only at Site- 

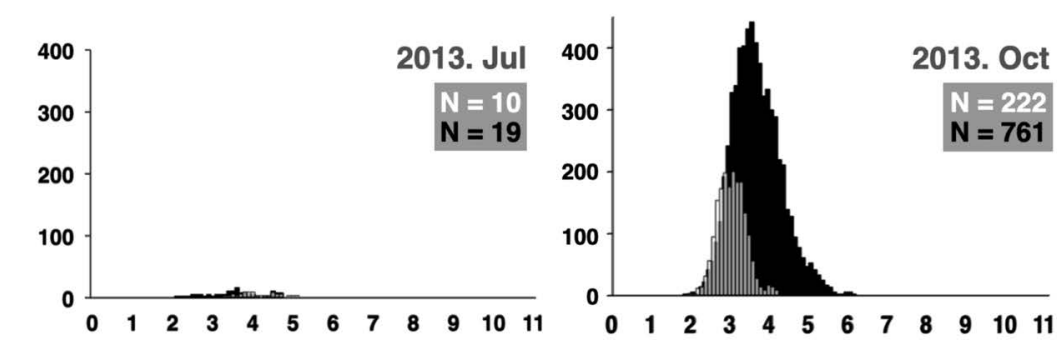

$\square: \operatorname{Stn} A$ 口: Stn B
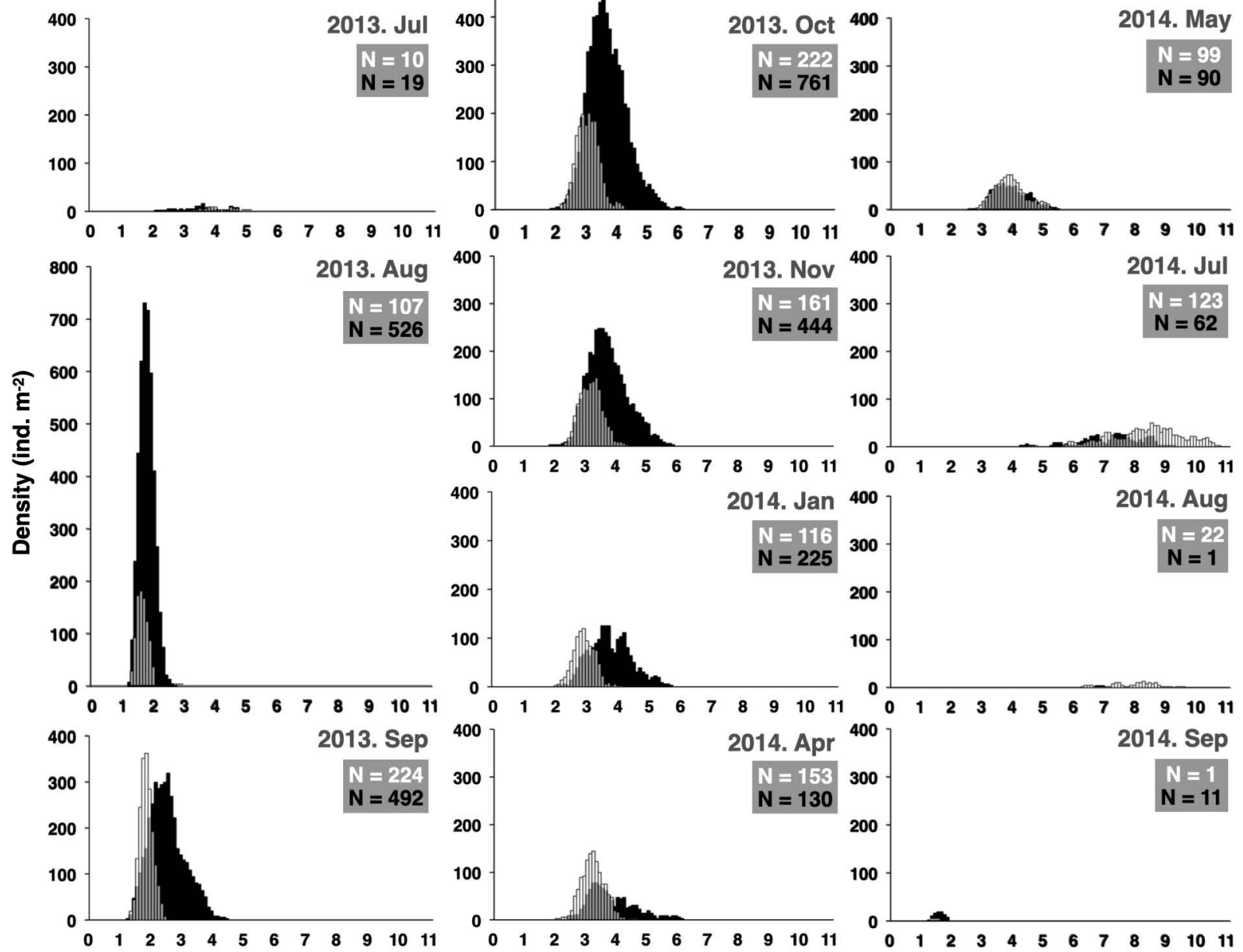

200

100
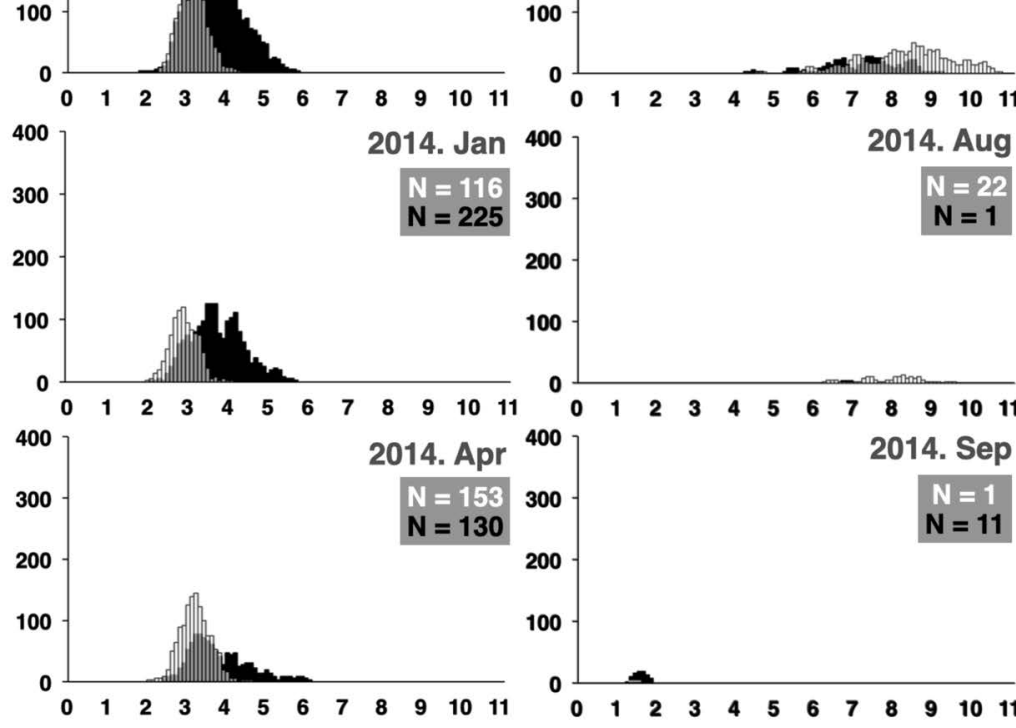

Shell length $(\mathrm{mm})$

Fig. 3. Size-frequency distribution of V. micra from July 2013 to September 2014.

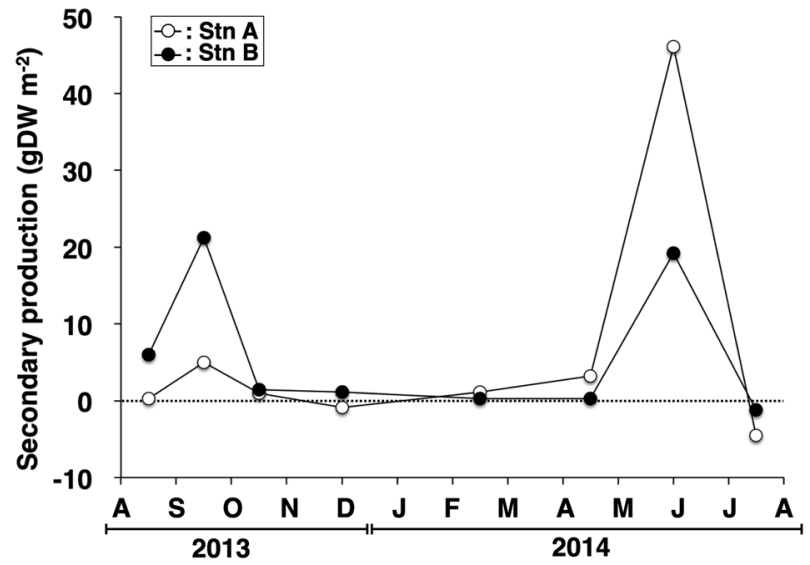

Fig. 4. Secondary production of $V$. micra during each sampling period from August 2013 to August 2014.

B (Fig. 6). At Site-B, fragments constituted $50.2 \%$ of the residual shell weight (paired shells, 12.5\%; half shells, $30.4 \%$; drilled shells, 6.8\%), whereas at Site-A, paired shells constituted $47.3 \%$ of the residual shell weight (half shells, 30.1\%; fragments, 22.5\%). These results implied that the major mortality factors for $V$. micra differed between the two sites, and the population of $V$. micra at Site$B$ could be more susceptible to physical damage because of external pressure crushing the shells.

\section{Discussion}

\section{Biological traits of $\boldsymbol{V}$. micra}

The life history of $V$. micra has been previously reported by Tanaka \& Kikuchi (1979), who described the size-frequency distribution of $V$. micra over 2 years. They speculated that $V$. micra exhibited an annual life cycle and has an extended reproductive season throughout the year, based on the observation of small individuals (1.5$2.3 \mathrm{~mm}$ ). However, in this study, the reproductive season was limited to summer (or late summer), judging from the timing of recruitment (Fig. 3) and the observation of gonad condition (Fig. 5). This discrepancy may be attributable to the difference in the shell length observed before winter. 
(a)

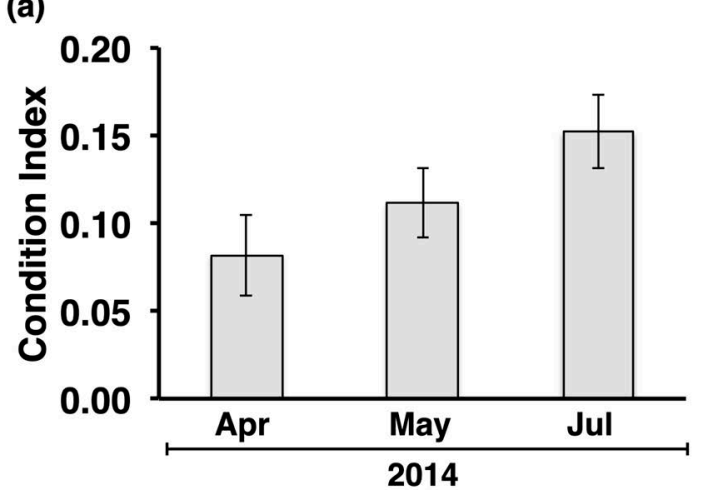

(b)

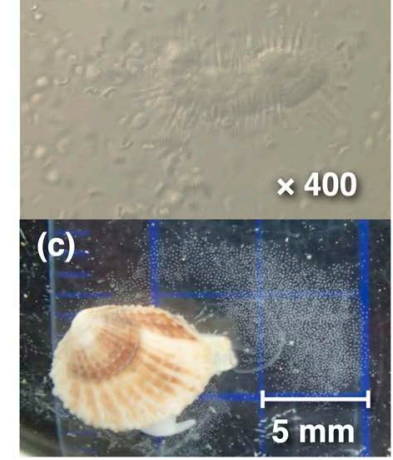

Fig. 5. (a) Condition index of $V$. micra from April 2014 to July 2014. (b) Sperm of $V$. micra. The specimen was collected at Site-A in July 2014. (c) A spawning individual during the sample treatment. The specimen was collected at Site-A in July 2014.

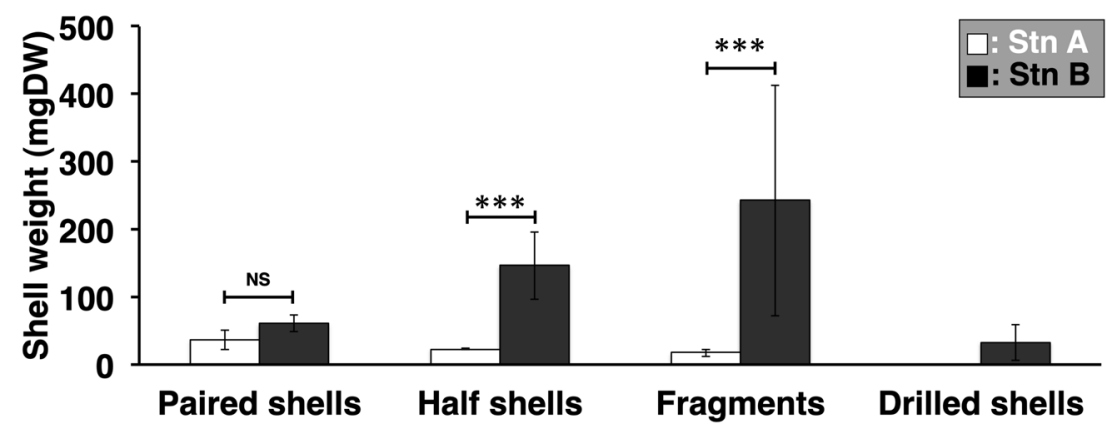

Fig. 6. Inter-site comparison of the amount of the classified residual shells. Significant differences determined by the likelihood-ratio test are indicated; NS (nonsignificant); ${ }^{* * *} p<0.001$

If recruitment was delayed and growth was not sufficient before winter, it is likely that shell length in the following spring did not change the size immediately after recruitment because of the low growth rate during winter (Fig. 3). In a study by Tanaka \& Kikuchi (1979), during years when several large individuals remained alive until September, recruitment was observed in late October, and small individuals, with 1-2 $\mathrm{mm}$ shell length, were observed during winter and the subsequent spring. Therefore, the small individuals observed during the winter and subsequent spring were not part of the recruitment, and the period from July to September could be considered the reproductive season of $V$. micra.

In this study, we observed the rapid growth of $V$. micra from May to July (Fig. 3). Rapid growth before summer is likely a typical biological trait of this species because the same growth patterns were confirmed by Tanaka \& Kikuchi (1979). Life-history tactics, such as rapid growth and early maturity, are favored in unpredictable environments (Stearns 1976). V. micra can mature before the severe decline of bottom water DO; therefore, rapid growth accompanying sexual maturation may be an advantage for reproductive strategies in environments subjected to seasonal hypoxia. Furthermore, high values of secondary production were recorded during this period (Fig. 4), which largely contributed to the annual secondary production of
V. micra (48.2-51.4 g DW m ${ }^{-2}$ year $\left.^{-1}\right)$. According to Tamai (1989), the annual secondary production of species that dominate the subtidal muddy bottom where seasonal hypoxia occurred was $1.8-6.3 \mathrm{~g} \mathrm{DW} \mathrm{m}^{-2}$ year $^{-1}$ for $V$. micra, 2.4-14.2 $\mathrm{g} \mathrm{DW} \mathrm{m}^{-2}$ year $^{-1}$ for Theora lubrica (bivalve), $0.01-0.18 \mathrm{~g} \mathrm{DW} \mathrm{m}^{-2}$ year $^{-1}$ for Paraprionospio cordifolia (polychaete), and $0.23 \mathrm{~g} \mathrm{DW} \mathrm{m}^{-2}$ year $^{-1}$ for Sternaspis scutata (polychaete). The annual secondary production of $V$. micra observed in this study significantly exceeded previously reported results, indicating that this species has the potential to significantly contribute to the material cycle in the muddy bottom ecosystem subjected to seasonal hypoxia.

\section{Differences in population dynamics of $V$. micra between sites}

In this study, differences in the surface sediment Chl- $a$ and AVS were observed between Site-A and Site-B during both years. In particular, reduced conditions of the surface sediment and slightly lower DO concentrations of bottom water were recorded at Site-A in August 2013 (Table 1). Following this hypoxic event, the shell growth of $V$. micra at Site-A decelerated, whereas that at Site-B progressed (Fig. 3). Studies have reported that some hypoxiatolerant bivalves can survive in oxygen-poor environments by increasing their anaerobic metabolism in response to 
reduced oxygen levels (e.g., Stickle et al. 1989, Ortmann \& Grieshaber 2003, Miyamoto \& Iwanaga 2012). V. micra exhibited a long survival period of up to $10 \mathrm{~d}$ under anoxic conditions (Yamada et al. 2016), suggesting that V. micra survives using anaerobic metabolism. Because anaerobic metabolism is less energy efficient than aerobic metabolism (Hochachka \& Somero 2002) and its metabolites impair shell formation (Tsutsumi 1989), increased anaerobic metabolism may cause a decline in growth. The poor growth at Site-A, where food supply (i.e., high Chl- $a$ ) was predicted to be higher than that at Site-B (Table 1), suggests that $V$. micra survived because of an increased rate of anaerobic metabolism during summer 2013. Therefore, the growth rates were different between the sites during the summer 2013 because of the difference in hypoxic condition, which was assumed from the difference in AVS at the two sites. In summer 2014, when there were no hypoxic waters, shell growth of $V$. micra appeared to accelerate at Site-A (Fig. 3), likely because of more abundant food resources than those at Site-B (Table 1).

The change in the population density of $V$. micra from October 2013 to May 2014 decreased more at Site-B than at Site-A (Fig. 3). Moreover, the condition of residual shells in the sediment at Site-B in July 2014 primarily consisted of fragments representing the crushing of shells by external pressure (Fig. 6). It is unlikely that the shells were broken by weak pressure because venerid species, known as bivalves, have a thick shell (Mikkelsen et al. 2006). One possible reason for the broken shells is that shells were crushed by predators. It has been reported that predators, such as mantis shrimp, blue crab, pufferfish, sea breams, octopuses, and rays, inhabit the inner part of Ariake Bay (Yamaguchi et al. 2005, Kyusyu Regional Agricultural Administration Office 2011). These predators have a tough organ that could crush shells, and they can use $V$. micra as a food source. In general, predation of infaunal macrobenthic organisms by secondary consumers, such as fishes, mantis shrimp, and blue crab, is low in severely hypoxic areas, but it increases upon recovery from hypoxia (Diaz et al. 1992, Phil et al. 1992, McAllen et al. 2009, Broszeit et al. 2013). The predation pressure may have been higher at Site-B because the decrease in DO concentration might not be severe and the recovery of DO concentration could be faster than that at Site-A (Table 1). Although further research is required to confirm the difference in predation pressure between sites, this difference could be a reason for the greater decline in the population density at Site-B during autumn.

Our results demonstrated that growth rates and survival patterns of the hypoxia-tolerant bivalve $V$. micra differed between the two sites with different conditions of sediment reduction, resulting in different temporal variation patterns in secondary production. In particular, our results suggest that the growth of $V$. micra is decelerated when the degree of hypoxia becomes more severe because the bivalves must rely on anaerobic metabolism for survival. To understand the biological traits of bivalve species that exhibit tolerance to hypoxic stress, it is necessary to consider and evaluate local hypoxic stresses in the field.

\section{Acknowledgements}

We would like to thank Kawaguchi Fishermen's Association for piloting the boat, Mr. Fumikazu Iwase, Ms. Shiho Muranaka, Mr. Hokuto Takashima, Ms. Hitomi Matsuno, Ms. Risa Takenaka, Mr. Shobu Ishimatsu, Mr. Tasuku Nishioka, Ms. Koito Shimada, Ms. Miharu Takada, Ms. Mari Matsumoto and Ms. Misato Tsuji for their assistance with the field survey. This work was supported by a Grantin-Aid for Scientific Research of the Japan Society for the Promotion of Science (representative; Tsutsumi H, No. 25281031 and Komorita T, No. 18K11625) and the Mitsui and Co., Ltd. Environment Fund (the representative; Hiroaki Tsutsumi, No. R09-B118).

\section{References}

Antonio ES, Kasai A, Ueno M, Won NI, Ishihi Y, Yokoyama H, Yamashita Y (2010) Spatial variation in organic matter utilization by benthic communities from Yura River-Estuary to offshore of Tango Sea, Japan. Estuar Coast Shelf Sci 86: 107-117.

Broszeit S, Davenport J, Bredendieck K, Harman L, McAllen R (2013) Seasonal oxygen-driven migration of mobile benthic fauna affected by natural water column stratification. Estuar Coast Shelf Sci 125: 36-42.

Diaz RJ, Neubauer RJ, Schaffner LC, Pihl L, Baden SP (1992) Continuous monitoring of dissolved oxygen in an estuary experiencing periodic hypoxia and the effect of hypoxia on macrobenthos and fish. In: Marine Coastal Eutrophication (eds Vollenweider RA, Marchetti R, Viviani R). Elsevier, Amsterdam, pp. 1055-1068.

Hochachka PW, Somero GN (2002) Biochemical adaptation: Mechanism and Process in Physical Evolution. Oxford University Press, New York, 466 pp.

Kyusyu Regional Agricultural Administration Office (2011) Fishery Production. Available at: https://www.maff.go.jp/kyusyu/ seibibu/isahaya/pdf/gaiyou2_5_13_01.pdf (accessed on 20 August 2021).

Matsukuma A (2000) Family Veneridae. In: Okutani T (ed) Marine mollusks in Japan. Tokai University Press, Tokyo, Japan. pp 1003-1019.

McAllen R, Davenport J, Bredendieck K, Dunne D (2009) Seasonal structuring of a benthic community exposed to regular hypoxic events. J Exp Mar Biol Ecol 368: 67-74.

Middelburg JJ, Levin LA (2009) Coastal hypoxia and sediment biogeochemistry. Biogeosciences 6: 1273-1293.

Mikkelsen PM, Bieler R, Kappner I, Rawlings TA (2006) Phylogeny of Veneroidea (Mollusca: Bivalvia) based on morphology and molecules. Zool J Linnean Soc 148: 439-521.

Miyamoto Y, Iwanaga C (2012) Biochemical responses to anoxia and hypoxia in the ark shell Scapharca kagoshimensis. Plankton Benthos Res 7: 167-174.

Nilsson HC, Rosenberg R (2000) Succession in marine benthic 
habitats and fauna in response to oxygen deficiency: analysed by sediment profile-imaging and by grab samples. Mar Ecol Prog Ser 97: 139-149.

Orita R, Umehara A, Komorita T, Choi JW, Montani S, Komatsu T, Tsutsumi H (2015) Contribution of the development of the stratification of water to the expansion of dead zone: a sedimentological approach. Estuar Coast Shelf Sci 164: 204-213.

Ortmann C, Grieshaber MK (2003) Energy metabolism and valve closure behaviour in the Asian clam Corbicula fluminea. J Exp Biol 206: 4167-4178.

Pihl L, Baden SP, Diaz RJ, Schaffner LC (1992) Hypoxiainduced structural changes in the diet of bottom-feeding fish and Crustacea. Mar Biol 112: 349-361.

Stearns SC (1976) Life-history tactics: a review of the ideas. Q Rev Biol 51: 3-47.

Stickle WB, Kapper MA, Liu LL, Gnaiger E, Wang SY (1989) Metabolic adaptations of several species of crustaceans and molluscs to hypoxia: tolerance and microcalorimetric studies. Biol Bull 177: 303-312.

Tamai K (1988) Estimation of marine benthic production: estimation of marine benthic production: Methods for the computation of production (2). Aquabiology 59: 452-455. (in Japanese)

Tamai K (1989) Estimation of marine benthic production: Estimation of the production based on the field data. Aquabiology 61: 130-135. (in Japanese)

Tanaka M, Kikuchi T (1979) Ecological studies on benthic macrofauna in Tomoe Cove, Amakusa. III. Life history and population fluctuation of major molluscs. Publ Amakusa Mar Biol Lab Kyushu Univ 5: 79-115.

Tanaka K, Okamura K, Kimoto K, Yagi H, Kodama M (2007) Citrate-dithionite-bicarbonate extractable phosphorus (CDB-
P) pool in the suspended and surface sediments of the tidal flat area in inner Ariake Bay, Japan. J Oceanogr 63: 143-148.

Tsutsumi H (1989) Environmental changes and evolution of marine invertebrates from the late Precambrian to the Cambrian. Benthos Res 35/36: 3-16. (in Japanese with English abstract)

Tsutsumi H (2006) Critical events in the Ariake Bay ecosystem: clam population collapse, red tides, and hypoxic bottom water. Plankton Benthos Res 1: 3-25.

Tsutsumi H, Takamatsu A, Nagata S, Orita R, Umehara A, Komorita T, Shibanuma S, Takahashi T, Komatsu T, Montani, S. (2015) Implications of changes in the benthic environment and decline of macro-benthic communities in the inner part of Ariake Bay in relation to seasonal hypoxia. Plankton Benthos Res 10: 187-201.

Vaquer-Sunyer R, Duarte CM (2011) Temperature effects on oxygen thresholds for hypoxia in marine benthic organisms. Glob Chang Biol 17: 1788-1797.

Yamada K, Miyamoto Y, Nakano T, Okamura K (2016) Interand intraspecific variation in anoxic survival among three bivalve species in intertidal and subtidal areas along the coast of Japan. Plankton Benthos Res 11: 49-56.

Yamaguchi A, Kawahara I, Ito S (2005) Occurrence, growth and food of longheaded eagle ray, Aetobatus flagellum, in Ariake Sound, Kyushu, Japan. Environ Boil Fishes 74: 229-238.

Yokoyama H, Hayashi I (1980) Zonation and species diversity of smaller macrobenthos in the westernmost part of Wakasa Bay (the Sea of Tango). J Oceanogr 36: 46-58.

Yoshino K, Hamada T, Yamamoto K, Hayami Y, Yamaguchi S, Ohgushi K (2010) Effects of hypoxia and organic enrichment on estuarine macrofauna in the inner part of Ariake Bay. Hydrobiologia 652: 23-38. 